\title{
The Regulatory and Supervision Framework of Microfinance in Kenya
}

\author{
Abd Elrahman Elzahi Saaid Ali ${ }^{1}$ \\ ${ }^{1}$ Islamic Research and Training Institute, Saudi Arabia \\ Correspondence: Abd Elrahman Elzahi Saaid Ali, Islamic Research and Training Institute, Saudi Arabia.
}

Received: June 11, 2015

Accepted: June 25, 2015

Available online: August 4, 2015

doi:10.11114/ijsss.v3i5.1004

URL: http://dx.doi.org/10.11114/ijsss.v3i5.1004

\begin{abstract}
Microfinance is one of the essential branches of lending that is used to mitigate the negative impact of the increasing incidence of poverty and unemployment in Kenya. This highlights the important need for an effective regulatory and supervisory framework for Microfinance Institutions (MFIs) in this country. This research attempts to investigate the performance of the Kenyan microfinance regulatory and supervisory framework through extracting and analyzing secondary data sources. Kenya has not unified the regulatory and supervisory framework for the microfinance sector based on the results of the logical descriptive analysis. The involvement of different bodies, which are include associations, clubs and churches, in regulation might have weakened the effectiveness of outreach and represents more challenges for the microfinance sector in Kenya. However, these results have strong implications for the regulators and the governments when they tried to regulate MFIs.
\end{abstract}

Keywords: Microfinance Regulatory System, poverty alleviation, Kenyan Microfinance

JEL Classification: G21, G23, G28

\section{Introduction:}

Like in other African countries, Kenya's association with weakness in infrastructure, security, land tenure, education, employment, and drought management strategies, has led to severe poverty particularly in the northern part of the country. The previous report showed that $50 \%$ of the Kenyan population are poor and hence has no access to formal banking. Based on the Financial Sector Deepening Trust (FSD) ${ }^{1}$, Kenyan banks serve no more than 4 million people, leaving the rest of the economically active population to depend on risky and expensive informal and semi-formal sources of finance. These sources of finance are not subject to the prudential regulations that apply to banks and other formal-sector institutions. The challenge is that informal and less regulated funds are highly expensive and sometimes beyond the capacity of the active poor. Because of these, the informal lenders themselves leverage and mobilize expensive capital from external resources.

The high level of poverty and the growing awareness of the role of microfinance drew the attention of the Kenyan Government to the importance of microfinance in alleviating poverty. Microfinance is the money loaned to low-income people or the economically active poor and small-scale enterprises that lack access to funds through the formal lenders. The Central Bank of Kenya (CBK) defines a microfinance institution (MFI) as an institution that offers financial services such as credit, savings, insurance, and money transfer services to the poor, low-income households, and Small and Medium Enterprises (SMEs) that do not qualify for, and therefore lack access to traditional formal financial institutions.

CBK broadly divides the microfinance institutions into deposit-taking and non-deposit-taking microfinance institutions. The deposit-taking microfinance institutions (DTMs) are licensed and regulated by the CBK and are permitted to mobilize and intermediate (or lend) deposits from the public. However, unlike commercial banks, DTMs can only engage in a limited range of products. They are not allowed to invest in enterprise capital; undertake wholesale or retail trade; underwrite place of securities; and purchase. On the other hand, non-deposit-taking microfinance institutions are regulated by the Ministry of Finance, and are not allowed to mobilize public funds. Thus, they can only lend their own funds or borrowed funds.

Both categories of MFIs support the economic activities of the youth, the marginalized and the poor, and SMEs

\footnotetext{
1 http://www.fsdkenya.org/

The researcher appreciates the efforts of Wahida Mohamed, the research assistant who helped in data collection
} 
contribute immensely towards poverty alleviation. Therefore, the sound development of a conducive regulatory and supervisory environment in Kenya should take into account the different categories of MFIs. In addition, facilitating their rapid growth is vitally important. Hence, this study attempt to investigate the effectiveness of Kenya current microfinance regulatory framework and suggest some modification for more improving if found ineffective.

\section{The Financial System Development of Microfinance Sector in Kenya}

The earliest forms of microfinance and microcredit in Kenya were church-based lending programs that arose in the 1980s. Most were confined to specific church parishes that started with local financing for members before they developed into institutions that could cover a wider number of people in the rural and suburban areas of Kenya. While these church-based lending programs served the primary function of providing credit to the members of their congregations, they were often very small and their operations are limited to specific geographic locations but with limited reach and financial resources. However, they still served the function of providing limited credit facilities to their members for use in specific purposes.

However, in many cases, these organizations were overwhelmed by the demand for credit by their membership. From the beginning, nongovernmental organizations (NGOs) began to fill this gap by extending the credit services more widely. Due to this, in the 1990s, the NGOs developed functioning systems to facilitate the administration of the credit delivery. The programs were funded and were not necessarily considered as outright business ventures in spite of the success that most of the schemes achieved.

As the successes of the microcredit institutions grew, they received considerable funding and began to turn into full commercial entities. This development was also supported by the increased competence in administration, credit assessment, and the organization of individuals into groups to facilitate the collective guarantee of loans by individual members. Thus, as the microfinance industry in Kenya grew, the institutions assumed various formal structures and were registered under different statutes.

In the 1990s, many microfinance institutions moved away from serving closed groups into more formalized institutions. This institutionalization required that the microfinance and micro-credit institutions should also move away from being subsidized institutions into more of commercial entities. Evidence of the growth and increasingly significant role played by the micro-credit and microfinance institutions is seen in the development of the K-Rep Bank. The K-Rep Bank is the first of the microfinance institutions in Kenya to develop into a full commercial banking enterprise. In order to conduct its business as a banking institution, the K-Rep Bank was registered under the Central Bank of Kenya Act (Cap 488).

The Kenyan banking sector has experienced a continued growth trajectory. It is developing and deepening faster than the overall economy. It grew by $9 \%$ in 2010 and $7.8 \%$ in 2011, while the economy grew by $5.8 \%$ and $4.4 \%$ in 2010 and $2011^{\text {ii }}$, respectively. This development within the financial sector is strongly guided by the medium-term objectives of the financial sector reform and development strategy embedded in the economic development blueprint, 'Vision 2030', which covers the period of 2008-2030. The 2030 vision for financial services is to create a vibrant and competitive financial sector that will create jobs and promote a high level of savings to finance Kenya's overall financial needs. It provides for the introduction of both legal and institutional reforms in the sector that will enhance transparency in all transactions, build trust, and make the enforcement of justice more efficient.

Therefore, Kenya is one of the first African countries that discovered the importance of microfinance as one of the essential tools for poverty eradication. The country exert more efforts to develop and promote microfinance business in its territory. Microfinance business in Kenya is usually carried out through different institutional forms. These institutions are formal, semi-formal, and non-formal microfinance providers. The formal institutions cover the commercial banks, non-bank financial institutions, microfinance companies, etc. Others are semi-formal such as co-operative societies, trusts, NGOs, and state corporations (such as the Uwezo Fund and Women's Enterprise Fund). In addition, there are other in-formal financial institutions, such as Rating Savings and Credit Association (ROSCAs), and Accumulating Saving and Credit Associations (ASCAs). The ROSCAs, ASCAs, and moneylenders are user-owned, and they are managed to offer products tailored towards the needs of their different communities (Figure 1). 


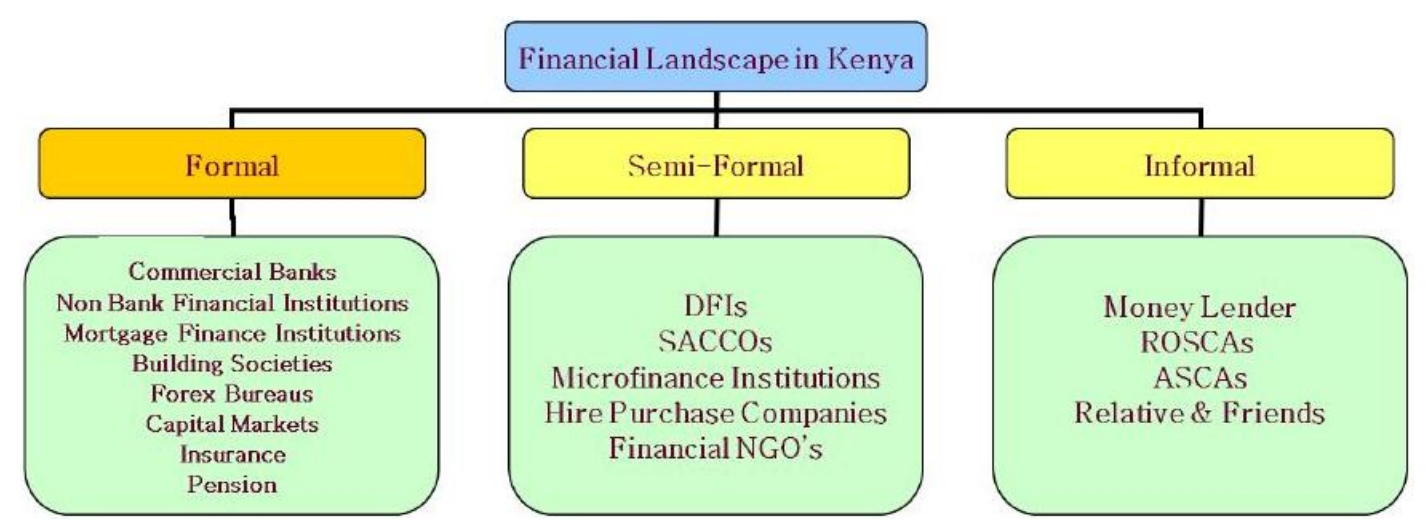

Figure 1.Kenya's Financial Sector Landscape

Recently, the total asset of the Microfinance Institutions (MFIs) in Kenya has increased steadily compared to the previous years. The growth was at an average of 30.4\% and are worth over KES 220bn (USD 2.59bn) as of December 2011, up from KES 129bn (USD 1.71bn) as of December $2009^{2}$.Equity bank represents the main contributor to this growth. It represents $80.4 \%$ of the total asset in the sector.

Despite this growth, Kenyan microfinance sector is still weak compared to the size of its clients. Recent reports showed that if commercial banks are excluded, the Kenya microfinance sector is less strong, and relatively stagnant. In 2011, DTMs recorded a negative growth despite the fact that there was an increase in the number of granted DTM licenses. However, the number of borrowers in this sector reached nearly 1.5 million with the value of the outstanding loan book standing at KES 138.4bn as of December 2011 (USD 1.6 bn), which represented positive growth trends. Total liabilities amount to KES 178.4bn (USD 2.2bn) as of December 2011 which showed steady growth trends of $40 \%$ in 2011 compared to $27.6 \%$ in 2010 . However, the sector largely funds itself with deposits collected from the public, which account for $58.9 \%$ of total assets. In addition, total equity accounts for $18.2 \%$ of total assets, followed by borrowings accounting for $16.6 \%$. Thus, the compulsory savings on the other hand, accounts only for $4.16 \%$ of the funding structure.

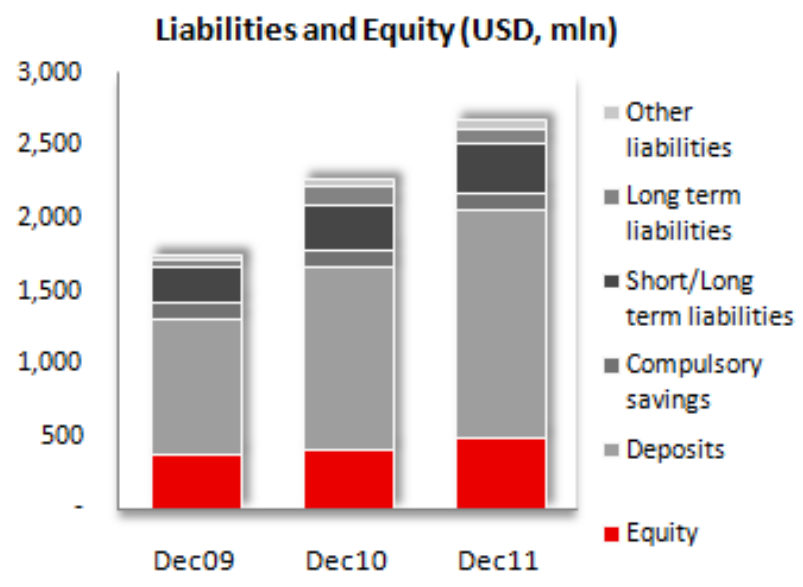

Figure 2. Liabilities and Equities of Kenyan MFIs

The report on Kenyan financial inclusion shows an increase in formal prudential. Figure 3 showed that formal financial inclusion grew $10.6 \%$ between 2009 and 2013 compared to a $7.1 \%$ growth between 2006 and 2009 . Thus, the growth of financial inclusion in Kenya has been reflected positively by the decrease in the proportion of people excluded for the same period. As indicated in Figure 3, the number of people excluded decreased gradually to 6\% between 2009 and 2013. This was a little less than the decrease between 2006 and 2009, which was recorded as $7.9 \%$.

The period between 2006 and 2009 also showed that the formal financial inclusion outperformed the informal financial inclusion. Hence, the proportion of people relying solely on informal types of financial services has been steadily decreasing from 33.3 in 2006 to 7.8 in 2013 as shown in figure 3. Likewise, the formal registered financial

2 _AMFI Kenya's 2012 annual report on 
inclusion also showed negative increase. The statistical status of the inclusion for the period between 2006 and 2009 clearly reflects the great efforts exerted by the Kenyan government in regulating the promotion of financial inclusion tools across the society, particularly the formal prudential inclusion.

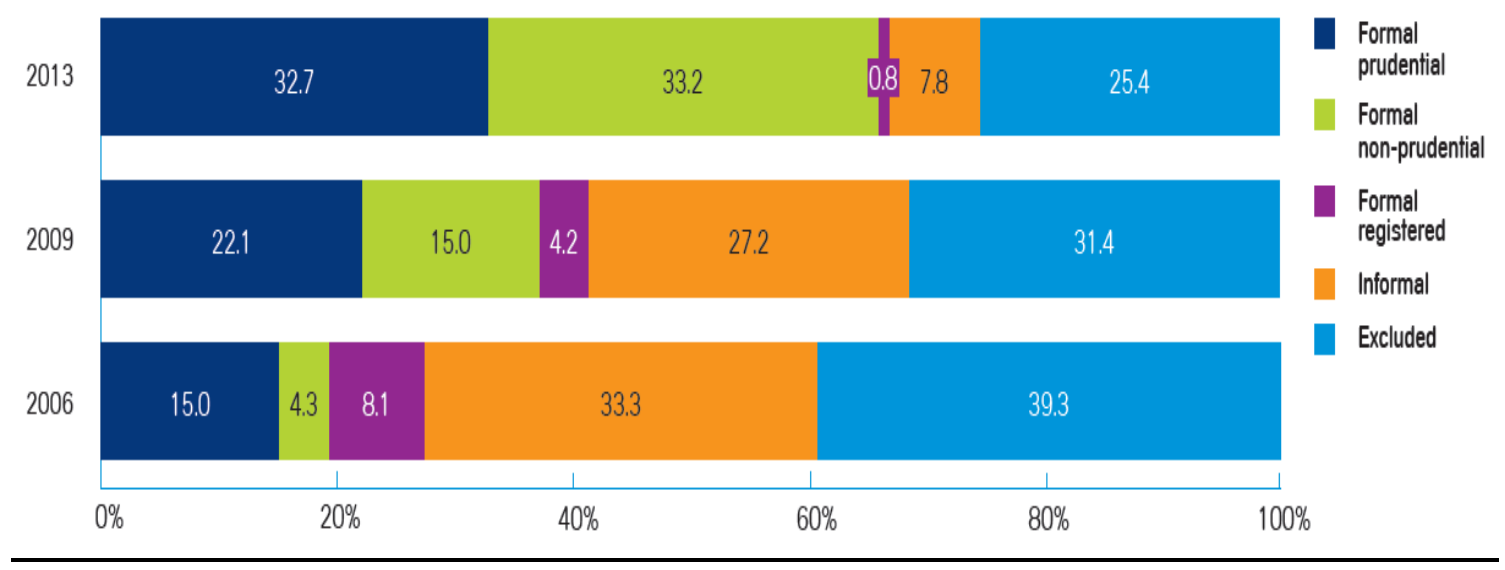

Figure 3. Access Strands by Year (\%)(Source FinAccess 2013 Report)

\section{Micro-finance Regulatory and Supervision Overview}

Current literature and actual practice show that the government and donor funds collectively could only supply a small fraction of global microfinance demand. Hence, financial intermediation by self-sufficient institutions is the only way that financial services can be supplied to lower-income people worldwide (Marguerite S. Robinson, 2001). Despite the importance of microfinance as a means of poverty alleviation and a labor-intensive sector, their providers face even the challenges of survival. The previous study argued that only the microfinance provider can cover its costs, continue its operations in a sustainable way, and generate benefits to its clients (H.Schmidt and Zeitinger, 2003). In order to promote microfinance effectively and maintain its sustainability, there must be a suitable regulatory system in place. The literature showed that microfinance institutions must be able to enter the arena of a licensed and prudentially supervised financial intermediation, while at the same time; regulations must be crafted in such a way that allows the effective and efficient development of the MFIs (Peck Cristen et al., 2003).

Therefore, the availability of a set of enforceable binding rules called prudential regulation or prudential supervision that govern the conduct of microfinance providers are essential. Prudential regulation refers to a set of general principles or legal rules that aims to contribute to the stable and efficient performance of financial institutions and markets (Chaves and Gonzalez_Vega, 1994). The purpose of prudential regulation is to ensure the financial soundness of financial intermediaries such as banks, microfinance institutions, etc., and to prevent financial system instability.

Many countries are applying different instruments of prudential regulation. Therefore, there is a variation on the type and scope of government regulation of depository financial intermediaries. The two frequently adopted instruments of regulation are preventive and protective regulation. The preventive regulation is a pre-crisis measure that is taken by external supervisors in order to reduce the probability of failure of the financial institutions. It tries to control the risk exposure of the financial system. The external supervisors use entry and ongoing requirements as instruments of preventive regulation. In addition, entry requirements ensure that only financially healthy institutions join the market place. The entry requirements are usually based on the minimum capital requirements, ownership criteria, feasibility studies, capital to asset ratio etc. This type of regulation is one of the most powerful actions that were taken by external regulators. Preventive regulation might be most difficult to apply in Kenyan microfinance sector. Kenya is associated by a less-regulated sector that follows different jurisdiction.

Protective regulation on the other hand is a post-crisis measure taken by external regulators to avoid run on deposits by assuring the depositors that they will be the first to withdraw the funds from the financial intermediaries. Protective regulatory instruments include government as a lender of last resort, deposit insurance, and the formalized process of financial intermediaries restructuring and reform.

The regulations, whether preventive or protective, need an effective enforcement framework called prudential supervision. Prudential supervision refers to the process of enforcing the regulatory framework (Chaves \& Vega G., 1994). It is an external oversight of the financial institution through examining and monitoring mechanisms to verify compliance with the approved regulations. Through effective supervision, financial institutions are monitored and directed to ensure that they comply with the regulatory requirements. 
Evidence showed that efficient regulatory policies are useless if not backed by the enforcement mechanisms of efficient supervision (Christen and Rosenberg, 2000). The prudential supervisory system works as an early warning for the financial system. Thus, the more important aspect in the supervisory role is the existence of effective and accurate supervisory indicators. Hence, the challenges that might face Kenyan regulatory authorities is to design effective supervisory indicators for measuring risks, monitoring, and analyzing the impact of external events on the performance of the microfinance services providers.

In addition, the effective mechanisms of supervision of financial institutions comprises offsite and on-site supervision. The off-site supervision is an early warning system based on the analysis of the data reported to the supervisory authority. On-site supervision such as CAMEL and PEARLS involves actual visits to the financial institutions to verify that the data fed to the off-site system are accurate. However, recent development indicated that central banks are moving towards introducing risk-based supervision approach. The main source of the microfinance institutions are external and internal auditors.

Adoption of a sound system of regulation and supervision framework has gained substantial attention at the top level. The rationale of that attention is to minimize the effects of market failure, protect public deposits and small depositors, ensure integrity and financial stability of financial systems, and promote efficient performance of the institutions. ${ }^{3}$ The regulatory framework of any country should therefore have a clear rationale and objectives for regulating the financial sector; otherwise, it will lead to wastage of scarce supervisory resources, unnecessary compliance burdens of licensed institutions, and development of the financial sector will be constrained. Hence, any authority needs to design an effective regulatory and supervisory system for microfinance that is flexible enough to comply with the diversity of clients, permit fairness and cost effectiveness. According to (Chaves and Gonzalez_Vega, 1994), the regulatory and supervisory system should be flexible enough to fit into the environment in which the MFIs operate, the market niches they serve, and their institutional design.

\section{Kenyan Microfinance Regulatory and Supervisory Legal Framework}

Despite the low growth of the Kenyan economy in recent years, the country's microfinance sector continues to evolve rapidly as shown previously for the years between 2006 and 2009. The country encourages the introduction of communication technology. Consequently, mobile money services are being used widely in Kenyan communities. This innovation and rapid development of many local efforts driven by the demand side to provide financial services to microfinance clients unreached through the formal channels, seem to have generally overtaken policy formulation by the Kenyan government. The country recently encouraged the regulator to formulate a regulatory system for microfinance_through mandated standards of performance that assist the financial sector in moving from a less-regulated environment to a tightly-regulated one. Kenyan microfinance sector is quite unlike the formal banking sector or like other microfinance sectors in the neighboring countries. In Kenya, the sector is regulated and supervised under different jurisdictions and laws. Because of that, it faces various challenges and constraints that might limit its role to achieve the desired level of outreach and sustainability.

There are primary and secondary legislation regulating the microfinance industry in Kenya. Kenya issued separate laws to promote microfinance. Despite of that microfinance in Kenya is regulated under different laws, including the banking law and the Microfinance Act, which was issued in 2006 and amended in 2013. Hence, the Microfinance Act $2006^{4}$ and the Central Bank of Kenya Act $^{5}$ primarily governed the industry.

The main objective of the Microfinance Act is to provide the legal, regulatory and the supervisory framework for the Deposit-Taking Microfinance Institutions (DTMs). The Act categorises the Deposit-Taking MFIs as nationwide MFIs (operating countrywide) with a minimum core capital of KES 60M (USD 860,000) and Community MFIs (operating within a specific administrative region) whose minimum core capital is KES 20M (USD 300,000). The Act makes provisions for MFI license issuance, revocation, and restriction; provides for MFI entry into regulated status; defines the minimum core capital requirements and prohibited activities; provides limits for loans or credit facilities; defines ownership and management structure; provides for supervision by CBK; and stipulates the terms for periodic reporting to the CBK.

The Microfinance (Amendment) Bill 2013 increased the range of financial services that the DTMs can offer. Moreover, the amended version has differentiated between the regulated microfinance institutions and the un-regulated microfinance lenders. This was because the law requires the regulated MFIs to incorporate the term DTM into their names. Therefore, the amended Act enhances market confidence in Kenya's microfinance sector. In addition, Section 14

\footnotetext{
3 Armstrong and et al., cited in Thankom Arun, 2004

${ }^{4}$ Laws of Kenya, the "Microfinance Act 2006", (Chapter 19)

5 Laws of Kenya, the "CBK Act", (Chapter 491)
} 
of the Microfinance Bill gives DTMs the right to issue third party checks, operate current accounts, and perform foreign trade operations. This recent amendment in the Kenyan microfinance law has transformed the DTMs into microfinance banks. This transformation will help in reducing their reliance on expensive loans from local and international banks for lending.

Hence, foregoing evidences support that microfinance sector in Kenya is regulated under the various primary and secondary legislations. Apart from Microfinance Deposit Taking Institutions, other microfinance providers regulated under different formality such as Building Societies, Churches. Based on that the sector, was expanded both formally and informally. Thus, there are a number of microfinance licenses issued under Kenya microfinance laws. These are about nine Deposit Taking Microfinance Banks providers, and 35 credit microfinance institutions. These are in addition to the informal microfinance institutions and development partners.

The second element after the primary and secondary legislation is the supervisory authority and delegation. The main supervisory authority for the deposit-taking microfinance institutions is the Central Bank of Kenya, while the non-deposit taking microfinance activities are delegated to be supervised by the Microfinance Finance Unit of the Ministry of Finance. Based on that, Kenya has defined three regulatory tiers. These tiers are defined under Deposit Taking Microfinance (DTM) Bill and they represent both formal and informal microfinance providers.

The DTM bill is intended to regulate the three different tiers of microfinance institutions. The first tier comprises formally constituted deposit-taking MFIs which are regulated and supervised by Central Bank of Kenya (CBK) via the Deposit Taking Microfinance Bill. The Bill empowers the CBK to license, regulate, and supervise formally constituted microfinance institutions intending to take deposits from members of the public. Furthermore, specific performance parameters and appropriate guidelines were developed to facilitate the supervision of this group of MFIs. This group of MFIs is also a member of the Deposit Protection Fund Board (a deposit insurance scheme) that protects depositors' deposit up to KES 100,000. The second tier comprises formally constituted credit-only MFIs that do not take deposits from the public, but can accept cash collateral tied to loan contracts. This tier is regulated and supervised by the Microfinance Unit in the Ministry of Finance through regulations issued by the Minister for Finance. The third tier consists of informal MFIs such as ROSCAs, club pools, and financial services associations (FSAs) which are not supervised by any government agency. However, donors, commercial banks, and government agencies from which they obtain funds or that support this group are obligated to carry out due diligence and make informed decisions about them.

In the year 2000, CBK set up a microfinance division in the Bank Supervision Department to participate in the drafting of the Microfinance Bill and to develop prudential guidelines/regulations to be used once the Bill was in place. In 2004, the Central Bank established a Rural Finance Department to address various policy issues concerning rural finance, including microfinance. This department, in liaison with the Financial Institutions Department, is involved in developing capacity to regulate and supervise those microfinance institutions that will be licensed under the DTM Bill.

Moreover, a full-fledged microfinance unit is envisaged at the Ministry of Finance to formulate policies and procedures to address the challenges facing microfinance institutions that are not supervised under the CBK, especially those in the rural areas. Also, they aim to build a database to facilitate better regulation and monitoring of their operations.

Likewise, an Association of Microfinance Institutions (AMFI) was registered in 1999 under the Societies Act by the leading MFIs in Kenya to build capacity for the microfinance industry. AMFI currently has 59 member institutions serving more than $6,500,000$ poor and middle class families with financial services throughout the country. AMFI is governed by a General Assembly and is led by a Board of Directors whose experienced practitioners are running some of the leading microfinance institutions in Kenya. AMFI's mandate is to enhance collective action by MFIs and other stakeholders to foster a conducive policy and regulatory environment for microfinance in Kenya. In addition, the association is to strengthen the capacity of MFIs in delivering appropriate and sustainable microfinance services to low-income people. That is through organization and coordination of workshops and training sessions; develop effective systems for information collection, analysis and dissemination; develop and operationalize a Performance Monitoring System for MFIs that will set standards and increase professionalism in the industry; and enhance collaboration, linkages and partnerships.

Moreover, Kenya has established a Financial Reporting Centre under the Proceeds of Crime and Anti-Money Laundering Act 2009 (the "AML Act") that was operational in 2012. The center's principal role is to assist in the identification of the proceeds of crime and the combating of money laundering. All banks, financial institutions, non-bank financial institutions, mortgage finance companies, and forex bureaus are obliged to monitor and report suspected money-laundering activities to the center, verify customer identity, establish and maintain customer records, and establish and maintain internal reporting procedures. With regard to cash transactions, the reporting threshold for reporting institutions is set at US\$10,000 or its equivalent in any other currency, irrespective of whether or not such 
transactions are suspicious.

The government issued new prudential guidelines to deal with a wide range of issues including licensing requirements, corporate governance, board composition, remuneration of directors, capital adequacy requirements, liquidity management, stress testing, foreign exchange exposure limits, prohibited business, anti-money laundering, consumer protection, enforcement of banking laws and regulations, agent banking, and representative offices. These guidelines are best summarized by reference to the circular issued by the CBK, which states that: "Pursuant to its mandate of fostering the liquidity, solvency, and proper functioning of a stable market-based financial system, the Central Bank of Kenya has conducted a comprehensive review of the Prudential Guidelines and Risk Management Guidelines currently in use. The review has been necessitated by developments in the national, regional, and global arenas and the need to proactively strengthen the regulatory framework for banks and other institutions licensed pursuant to the Banking Act."

As part of Kenya's recent move to bring in adequate measures for consumer protection and to prevent money laundering, the CBK has also published Retail Transfers Regulation, 2013 for the provision and regulation of electronic retail transfers and e-money. Stakeholders were invited to review and comment on this draft regulation before it was enforced. This regulation applies to all retail transfers utilizing an electronic payment method, as well as all payment service providers that are not licensed as banks or financial institutions. The country has launched a credit information-sharing mechanism in July 2010 that might positively affect the MFI operations. Through a mechanism that is used by both individual and commercial banks, the CBK has ensured that banks strengthened credit appraisal standards by incorporating credit reference reports in the credit risk appraisal. Moreover, Kenya Deposit Insurance Act 2012 provides for the establishment of an autonomous body called the Kenya Deposit Insurance Corporation, which will replace the current Deposit Protection Fund Board, a department of the CBK. The KDI Act provides for the setting up of a deposit insurance system, and the liquidation of deposit-taking institutions.

The above argument indicates that regardless of some shortcomings associated with the diversity of the regulatory and supervisory Acts, rules, and bodies, Kenya has set clear guidelines for suspending, canceling, or revoking microfinance licenses for illegitimate operations in cases where institutions cannot achieve acceptable performance and operating standards for deposit takers and for the informal microfinance providers. Despite the performance of Kenyan microfinance sector, it is still below the required level, which proved that the regulatory and supervisory rules alone are helpless for microfinance sector outreach.

\section{Summary and Conclusion Remarks}

Most of the literature in the area of regulating and supervising MFIs confirms that the microfinance sector must be regulated in order to have massive and sustainable delivery of financial services to the low-income people. Therefore, the issue of prudential regulation and supervision might be one of the key successes for MFIs; yet, it is also a complex matter because it keeps evolving. This article is an attempt to generate some evidence from Kenya's regulatory and supervisory framework for microfinance through identifying its challenges and binding constraints that might hinder its outreach for the clients countrywide.

The results showed that regardless of some shortcoming associated with the diversity of the regulatory Acts and bodies, Kenya set clear guidelines for operating, suspending, canceling, or revoking microfinance licenses for a successful handling of microfinance formal and informal institutions. This helps the regulated MFIs to strategize their operations in such a way that avoids poor financial and operating performance. Despite that, the existence of more regulatory and supervisory bodies involved in regulating and supervising microfinance providers in Kenya such as clubs, associations, apart from KCB and the Ministry of Finance, might represent the main challenges, which have weakened the regulation process. The informal microfinance sector is less regulated and associated with high risk. Hence, there is a need for development of appropriate documentation tools/procedures, management information systems, governance and internal control systems, particularly for the less-regulated tiers. The microfinance sector in this country and particularly the informal sector lacks the expertise, which spotlights the need for capacity building to enhance operations and improve risk management. Moreover, the high costs of transformation and operation, licensing, and the cost of stiff competition from other financial institutions have hindered the performance of the DTMs. It is also worthy to note that many MFI are moving towards the use of mobile phones for various transactions; yet there seems to be minimal regulatory or supervisory framework in place to supervise these popular and globally acclaimed services.

Hence, one this research might recommend Kenya to adopt more unified microfinance model regulated between the Central bank for deposit taking microfinance providers and the rest such as non-formal microfinance provider might be under the Ministry of Finance with the assistance of the ministry of interior for the security matter.

Finally, Kenya needs to conduct further revision on the framework of regulation and supervision of its microfinance sector since it might lead to performance improvement, thus enhancing the necessary resources mobilization for poverty alleviation. This improvement in financial performance can be attributed to access to cheaper funds, which can then 
be lent to the MFI customers as compared to dependence on expensive credit from macro-financial institutions.

\section{References}

Albino, D. O. Micro-finance Unit, Bank of Southern Sudan, Microfinance in Sudan, Regulatory framework and Vision

Anne P. (2012). The Regulation and Supervision of Microfinance: The International Institute for Sustainable Development.

Bikki, R., Joselito, G. (2003). Microfinance Regulation in Tanzania: Implications for Development and Performance of the Industry Africa Region Working Paper Series.

Cassian, J. N. (2008). Central Bank of Kenya, The Status Of The Microfinance Industry In Kenya Presentation At The 5th Afraca Microfinance Forum 2nd - 4th July 2008 Cotonou, Benin

Chaves, R., \& Gonzalez-Vega, C. Principles of Regulation and Prudential Supervision and Their Relevance for Microenterprise Finance Organizations.

David, K. (2005). Bank of Uganda, Uganda's Experience with the Regulatory and Supervisory Framework for Microfinance Institutions.

David. L. K. Uganda's Experience with Tiered Banking Regulation

George O. Central Bank of Kenya, March 2005 Regulation And Supervision Of Microfinance Institutions In Kenya

Hennie van Greuning Joselito Gallardo Bikki Randhawa. A Framework for Regulating Microfinance Institutions, Financial Sector Development Department, The World Bank, December 1998. http://www.fsdkenya.org/

Marguerite, S. R. (2001). The Microfinance revolution: Sustainable Finance for the poor.

Michael, F. (2001). Prudential Regulation and Supervision for Agricultural Finance, Food and Agriculture Organization of the United Nations.

Reinhard H. S., \& von Pischke, J. D. Networks of Micro and Small enterprise banks: a contribution to financial sector development, Frankfurt and Washington.

Robert, P. C., Richard, R. (2000). The Rush to Regulate: Legal Frameworks for Microfinance, Consultative group to assist the poorest (CGAP).

Robert, P. C., Timothy R. L., \& Richard, R. (2003). Microfinance Consensus Guidelines @ 2003 by CGAP/The World Bank Group.

Sonal, S., \& Mona, D. A., \& Khanna. Banking Regulation: Kenya, Global Legal insights, 1st Edition

Special Issue, Kenya Gazette, Supplement No. 169 (Acts No. 41) Acts, 2013 Nairobi, 2nd December, 2013 The Microfinance (Amendment) Act, 1101.

Stefan, S. Regulatory Requirements for Microfinance, A Comparison of Legal Frameworks in 11 Countries Worldwide Deutsche Gesellschaft fürTechnische Zusammenarbeit (GTZ) GmbH, 2003

Arun, T. G., \& Turner, J. D. Corporate governance of banks in developing economies: concepts and issues 2004 www.amfikenya.com

Yigrem, K. (2010). National Bank of Ethiopia, Regulation \& Supervision of Microfinance Business in Ethiopia: Achievements, Challenges \& Prospects, presentation at the International Conference On Microfinance Regulation, March 15-17. Bangladesh, Dhaka

\section{$(\mathrm{cc}) \mathrm{Br}$}

This work is licensed under a Creative Commons Attribution 3.0 License.

\footnotetext{
i http://www.bu.edu/bucflp/files/2012/01/Central-Bank-of-Kenya-Act.pdf

ii https://www.centralbank.go.ke/index.php/acts/.../153-2012-annual-report
} 